\title{
Evaluation of Biochemical Markers Correlated with Breast Cancer Young Patients
}

\author{
XENIA BACINSCHI, OANA SAPTEFRATI, ANCA ZGURA, LAURA ILIESCU, \\ BOGDAN HAINEALA, ELVIRA BRATILA, CLAUDIA MEHEDINTU*, \\ RAZVAN-COSMIN PETCA, AIDA PETCA, RAMONA ILEANA BARAC, \\ RODICA ANGHEL
}

Carol Davila University of Medicine and Pharmacy, 8 Eroii Sanitari Blvd., 050474, Bucharest, Romania

\begin{abstract}
Breast cancer ranks first in women in terms incidence and mortality in the world. In Romania its frequency continues to increase and now is the most common cancer in the women. Despite therapeutic advances, there is still severe cancer with heavy sequelae both physical and mental. It's even harder to accept or even reject when it comes to a young women. For a long time, breast cancer was linked to a more or less old age. However, in the recent literature, breast cancer is on the rise more observed in a young population, its frequency is estimated at $7 \%$ all cases of breast cancer. Breast cancer diagnosed in young patients tends to be more aggressive than the rest of the cases. In this paper, we present the results of a study that included 59 women presenting primary invasive breast carcinomas selected from the database of the Institute of Oncology Bucharest in which clinical follow-up data cover long intervals of time (2014 - 2019) and whose histological pieces met technical conditions optimal for extended immunohistochemical processing. The available material resources allowed the completion of a complete analyzes in all cases in relation to the immunohistochemical examination. The correlation between the expression of each of the antibodies was calculated using Pearson correlation coefficient.
\end{abstract}

Keywords: Breast cancer, young age, grade tumors, prognosis, HER2

\section{Introduction}

Breast cancer ranks first in women in terms incidence and mortality in the world[1]. In Romania its frequency continues to increase and now is the most common cancer in the women, and is therefore a real public health problem [2]. Despite therapeutic advances, there is still severe cancer with heavy sequelae both physical and mental. It's even harder to accept or even reject when it comes to a young women. For a long time, breast cancer was linked to a more or less old age. However, in the recent literature, breast cancer is on the rise more observed in a young population, its frequency is estimated at $7 \%$ all cases of breast cancer $[3,4]$.

The prognosis of patients under 35-40 years of age is often more reserved, with a tumor presentation that differs from that of older ones: larger size, worse tumor differentiation, higher proliferation index, lower expression of hormone receptors (close $50 \%$ versus $70 \%$ in older patients) and a higher rate of lymph node metastasis. Regardless of these usual risk factors, age 35 years remains a negative prognostic factor altering 4.4 times relapse-free survival, 3.2 times the risk of distant metastases, and 2.9 times overall survival [5] . The biology of breast cancer in young women is indeed different from that in older women and this is also evident from genomic analysis studies. [6-7]

The aim of the study was to evaluate the impact of age in breast cancer patients in relation to histological and immunohistochemical parameters, the degree of histological differentiation G, estrogens receptor ER, progesterone receptor PR, HER 2 status, and the proliferation index KI-67 to increase the impact on the prognosis and management of this patients.

*email: claudiamehedintu@yahoo.com 


\section{Materials and methods}

The retrospective study was conducted on a group of 59 women presenting primary invasive breast carcinomas selected from the database of the Institute of Oncology Bucharest in which clinical followup data cover long intervals of time (2014 - 2019) and whose histological pieces met technical conditions optimal for extended immunohistochemical processing (variants morphopathological being ductal invasive, lobular or mixed, in the absence of chemotherapy neoadjuvant). The available material resources allowed the completion of a complete analyzes in 59 cases in relation to the immunohistochemical evaluation .

This study was reviewed and approved by the Institute of Oncology Bucharest. The clinical characteristic of all the patients were obtained from their medical records.

The correlation between the expression of each of the antibodies was calculated using Pearson correlation coefficient. In all the analyses, the differences were considered significant at $\mathrm{P}<0.05$. Statistical analyses were carried out using SPSS.

\section{Results and discussions}

In this study, 59 women were diagnosed with invasive primary breast carcinoma with a mean age of 34.14 years (extremes: 24-40 years). Among 59 patients, $66.1 \%$ expressed ER, PR, and 33.9\% not expressed ER/PR. The proportion of patients overexpressing HER2 was 13.6\%. Grade 3 represented the majority, $66.1 \%$, followed by the 2 nd degree $28.1 \%$. The mean value of the proliferation index $\mathrm{Ki}$ 67 in our study was $36.68 \%$, with values between $1 \%$ and $80 \%$. The increased value of the proliferation index has been shown to be associated with a worse prognosis of the disease in young patients. [8,9]. St. Gallen criteria help in therapeutic decision making it possible to classify patients into risk groups and in 2019 there was no discussion about the Ki-67 values; the focus was on include the analysis of tumor infiltrating lymphocytes (TILS) for the purpose indication or de-escalation of the chemotherapy based on high TILS and establishing cut-off prescription of endocrine therapy for ERpositive tumors, but in 2011 and 2013, the use of proliferation index was recommended for the analysis of cellular proliferation, and for identifying the differentiation of luminal subtype of breast cancer [10].

Table 1. Independent prognostic factors associated with histologic grade

\begin{tabular}{|c|c|c|c|c|c|c|c|c|}
\hline \multicolumn{2}{|r|}{ Grade } & $\mathrm{N}$ & Range & Minimum & Maximum & Mean & $\begin{array}{c}\text { Std. } \\
\text { Deviation } \\
\end{array}$ & Variance \\
\hline \multirow[t]{3}{*}{ G1 } & Ki67 & 3 & 74 & 1 & 75 & 28.67 & 40.377 & 1630.333 \\
\hline & Age & 3 & 1 & 35 & 36 & 35.33 & .577 & .333 \\
\hline & $\begin{array}{c}\text { Valid N } \\
\text { (listwise) }\end{array}$ & 3 & & & & & & \\
\hline \multirow[t]{3}{*}{ G2 } & Ki67 & 17 & 65 & 5 & 70 & 33.41 & 21.281 & 452.882 \\
\hline & Age & 17 & 10 & 28 & 38 & 34.53 & 2.528 & 6.390 \\
\hline & $\begin{array}{l}\text { Valid N } \\
\text { (listwise) }\end{array}$ & 17 & & & & & & \\
\hline \multirow[t]{3}{*}{ G3 } & Ki67 & 39 & 70 & 10 & 80 & 38.72 & 18.663 & 348.313 \\
\hline & Age & 39 & 16 & 24 & 40 & 33.87 & 3.373 & 11.378 \\
\hline & $\begin{array}{l}\text { Valid N } \\
\text { (listwise) }\end{array}$ & 39 & & & & & & \\
\hline
\end{tabular}

From the analysis of the Ki-67 proliferation index in correlation with age and histological grade resulted that the younger age of the patients was associated with an increased Ki-67 value as shown in Table 1. 
Table 2 . Independent prognostic factors associated with her2 expression

\begin{tabular}{|c|c|c|c|c|c|c|c|c|}
\hline \multicolumn{2}{|c|}{ HER } & $\mathrm{N}$ & Range & Minimum & Maximum & Mean & $\begin{array}{c}\text { Std. } \\
\text { Deviation }\end{array}$ & Variance \\
\hline \multirow[t]{3}{*}{ negative } & Ki67 & 51 & 79 & 1 & 80 & 36.75 & 20.635 & 425.794 \\
\hline & Age & 51 & 16 & 24 & 40 & 34.24 & 3.057 & 9.344 \\
\hline & $\begin{array}{c}\text { Valid N } \\
\text { (listwise) }\end{array}$ & 51 & & & & & & \\
\hline \multirow[t]{3}{*}{ positive } & Ki67 & 8 & 65 & 10 & 75 & 36.25 & 20.659 & 426.786 \\
\hline & Age & 8 & 10 & 28 & 38 & 33.50 & 3.251 & 10.571 \\
\hline & $\begin{array}{c}\text { Valid N } \\
\text { (listwise) }\end{array}$ & 8 & & & & & & \\
\hline
\end{tabular}

The comparisons between patients overexpressing HER2, Ki-67 and age, showed that KI-67 has the same value both in the HER2 positive patients' group and in the HER2 negative patients' group . Statistical analysis also showed that young patients with positive HER2 had higher Ki-67 proliferation rate. The mean value for Ki-67 is lower for the HER group (positive) $=36.25$ than for the HER group $($ negative $)=36.75($ Table 2$)$.

Although there is a difference, this is not statistically significant $(\mathrm{p}>0.05)$

Table 3. Independent prognostic factors associated with er expression

\begin{tabular}{|c|c|c|c|c|c|c|c|c|}
\hline \multicolumn{2}{|c|}{ ER } & $\mathrm{N}$ & Range & Minimum & Maximum & Mean & Std. Deviation & Variance \\
\hline \multirow[t]{3}{*}{ negative } & Ki67 & 20 & 65 & 10 & 75 & 39.15 & 18.771 & 352.345 \\
\hline & Age & 20 & 12 & 28 & 40 & 34.40 & 3.299 & 10.884 \\
\hline & $\begin{array}{c}\text { Valid N } \\
\text { (listwise) }\end{array}$ & 20 & & & & & & \\
\hline \multirow[t]{3}{*}{ positive } & Ki67 & 39 & 79 & 1 & 80 & 35.41 & 21.398 & 457.880 \\
\hline & Age & 39 & 15 & 24 & 39 & 34.00 & 2.974 & 8.842 \\
\hline & $\begin{array}{c}\text { Valid N } \\
\text { (listwise) }\end{array}$ & 39 & & & & & & \\
\hline
\end{tabular}

Among 59 patients, $66.1 \%$ expressed ER, PR, and 33.9\% not expressed ER/PR. The age was the same in both groups, the difference was observed in the group of patients with the subtype triple negative where it was observed that the value of the proliferation index was higher than in the group of patients who had estrogen receptors (Table 3 ).

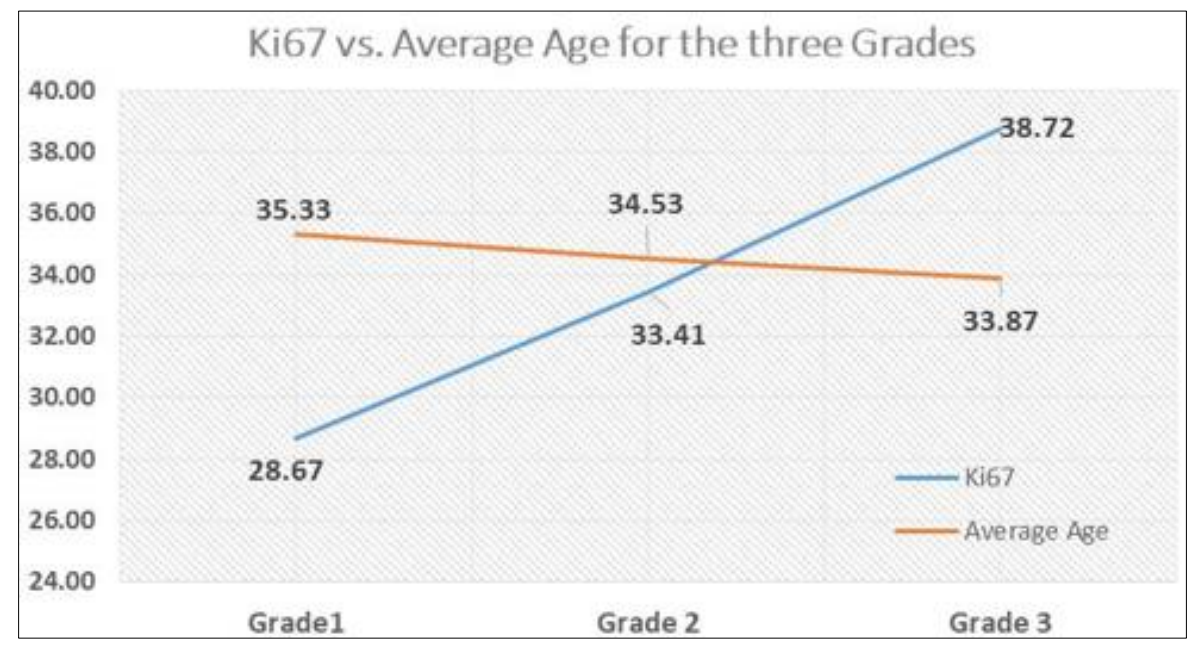

Figure 1. 1 Ki-67 vs. Average Age and histologic grade 
From the evaluation of age in relation with the proliferation index Ki-67 and histological grade, it was found that the value of the index Ki-67 increases according to the histological grade.

The mean age of 33 years was associated with the degree of histological differentiation G3 and si represented in Figure 1 and Table 1.

The correlation between Ki-67 and Age is negative, -0.147 (Pearson correlation coefficient) but not statistically significant (has a $\mathrm{p}=0.266>0.05$ ). The trends identified (these directions of correlation) although existing are very small and so it is recommended to continue the investigation on larger samples.

The IHC evaluation of HER2, estrogen receptors and progesterone having a direct impact on the therapeutic approach for young patients with breast cancer. HER2 is a membrane protein from the family of epidermal growth factor receptors (EGFR). This protein is overexpressed in 15 to $30 \%$ of breast cancers and is an unfavorable prognostic factor. Trastuzumab (Herceptin) is a humanized antibody targeting the HER2 protein. The benefit of this substance in the adjuvant treatment of HER2positive breast cancers has been demonstrated in recent years by the preliminary results of four large international studies: a 35 to 50\% reduction in the risk of relapse and a third in mortality. Determination of HER2 therefore has a significant impact on the prognosis and management of patients with breast cancer.

The mean age of our study population was independent of HER2 status, although young women overexpressed HER2. Similar results were observed by several authors [11-14].

The expression of estrogen receptors (RE) and progesterone (RP) is currently determined by IHC. It is currently recommended to specify the percentage of positive cells, which reflects the sensitivity of the cells to hormone therapy. In some centers, the results are given in the form of a score taking into account not only the percentage of positive cells, but also intensity of the labeling. However, this last parameter is highly dependent on the technical conditions (fixation and antigenic restoration). During the analysis, invasive carcinoma must be distinguished from carcinoma in situ. The reliability of a negative result implies a positive internal control (marked normal ductal epithelium)

The Ki-67 cut-off value for young breast cancer patients was identified as $36 \%$. Tumors with a Ki67> $14 \%$ are considered proliferative tumors and a correlation was observed between young age, high tumor grade, ER negativity, and HER-2 positivity (Figure 1).

"Triple negative" breast cancers represents about a quarter of breast cancers and is characterized by the absence of hormone receptors for estrogen and progesterone and the lack of HER-2 growth factor overexpression in immunohistochemistry. This breast cancer subtype is associated with a clinical profile unfavorable with a high risk of early metastatic relapse due to the aggressive nature of these tumors, of their part response High Ki-67 levels are often observed in triple-negative subtype cases. Were studied 496 triple-negative subtype womans with lymph node-negative and a mean age of 52 years and a median Ki-67 value of $48 \%$. The study showed that the proliferation index increased with decreasing age and histologic grade [15].

The overexpression of HER2, the high tumor grade, and the young age of our study population are unfavorable clinicopathologic factors supported by data from the literature [16-22].

\section{Conclusions}

Although the incidence of breast cancer young patient continues to increase in many countries, the mortality linked to this pathology has significantly decreased.

This favorable development is certainly the consequence of the earlier diagnosis by mammographic screening, but also of the progress made in adjuvant treatments. Breast cancer is a heterogeneous disease. The risk of relapse varies enormously depending on the age of the patient, the stage of tumor extension at diagnosis, and the biology of tumor cells which is increasingly seen as a deciding factor. The Ki-67 cut-off value for young breast cancer patients was identified as 36\%. Tumors with a Ki-67> $14 \%$ are considered proliferative tumors and a correlation was observed between young age, high tumor grade, ER negativity, and HER-2 positivit. Better discrimination between patients who would 
benefit from adjuvant therapy and those who could be spared is essential for optimizing the benefit / risk and benefit / cost ratios. The molecular approach, by analyzing the expression of a large number of genes, could soon lead to better efficiency, but still requires further clinical validation.

\section{References}

1. GLOBOCAN. Estimated Incidence, Mortality and Prevalence Worldwide in 2018, https://gco.iarc.fr/today/data/factsheets/populations/900-world-fact-sheets.pdf. (accessed on 10 june 2020).

2. GLOBOCAN. Estimated Incidence, Mortality and Prevalence Worldwide in 2018 https://gco.iarc.fr/today/data/factsheets/populations/642-romania-fact-sheets.pdf, (accessed on 20 june 2020).

3. SIEGEL, RL., MILLER, KD., JEMAL, A., Cancer statistics, CA Cancer J Clin, 66(1), 2016, 7-30

4. NAROD, SA., Breast cancer in young women, Nat Rev Clin Oncol, 9, 2012, 460-70.

5. FERGUSON, NL., BELL, J., HEIDEL, R., et al., Prognostic value of breast cancer subty pes, Ki-67 proliferation index , age, and pathologic tumor characteristics on breast cancer survival in Caucasian women, Breast J, 19, 2013, 22-30.

6. HAN, W., KIM, SW., PARK, IA., et al., Young age: an independent risk factor for disease-free survival in women with operable breast cancer, BMC Cancer, 4, 2004, 82.

7. BRENNAN, M., FRENCH, J., HOUSSAMI, N., ET AL., Breast cancer in young women, Aust Fam Physician, 34, 2005, 851-5.

8. FERLAY, J., SHIN, H., BRAY, F., ET AL., GLOBOCAN 2008 v2.0, Cancer Incidence and Mortality Worldwide: IARC CancerBase, Lyon, France: International Agency for Research on Cancer, 10, 2010.

9. CALDARELLA, A., CROCETTI, E., BIANCHI, S., ET AL., Female breast cancer status according to ER, PR and HER2 expression: a population based analysis, Pathol Oncol Res, 17, 2011, 753-8.

10. GAJDOS, C., TARTTER, PI., BLEIWEISS, IJ., ET AL., Stage 0 to stage III breast cancer in young women, J Am Coll Surg, 190, 2000, 523-9.

11. HARRIS, LN., ISMAILA, N., MCSHANE, LM., ANDRE, F., COLLYAR, DE., GONZALEZANGULO, AM., HAMMOND, EH., KUDERER, NM., LIU, MC., MENNEL, RG., ET AL., Use of biomarkers to guide decisions on adjuvant systemic therapy for women with early-stage invasive breast Cancer: American Society of Clinical Oncology clinical practice guideline, J Clin Oncol, 34(10), 2016, 1134-50.

12. ANDERS, CK., HSU, DS., BROAD, W., ATER, G., ET AL., Young age at diagnosis correlates with worse prognosis and defines a subset of breast cancers with shared patterns of gene expression, $J$ Clin Oncol. 26, 2008, 3324-30.

13. COlLinS, LC., MAROTTI, JD., GELBER, S., ET AL., Pathologic features and molecular phenotype by patient age in a large cohort of young women with breast cancer, Breast Cancer Res Treat, 131, 2012, 1061-6.

14. CAREY, LA., PEROU, CM., LIVASY, CA., ET AL., Race, breast cancer subtypes, and survival in the Carolina Breast Cancer Study, JAMA, 295, 2006, 2492-502.

15. YANG, XR., SHERMAN, ME., RIMM, DL., ET AL., Differences in risk factors for breast cancer molecular subtypes in a population-based study, Cancer Epidemiol Biomarkers Prev, 16, 2007, 43943.

16. CARVALHO, FM., BACCHI, LM., SANTOS, PP., ET AL., Triple-negative breast carcinomas are a heterogeneous entity that differs between young and old patients, Clinics (Sao Paulo), 65, 2010, 1033-6.

17. PETCA, A., RADU, D.C., PETCA, R.C., MEHEDINTU, C., BARAC, R.I., IONESCU, A., Current Trends of Liquid Chromatography Tandem Mass Spectroscopy Use in Clinical Gynecology, Rev. Chim., 70(6), 2019, 2021-2025. 
18. PARISE, CA., BAUER, KR., BROWN, MM., CAGGIANO, V., Breast cancer subtypes as defined by the estrogen receptor (ER), progesterone receptor (PR), and the human epidermal growth factor receptor 2 (HER2) among women with invasive breast cancer in California, 1999-2004, Breast J, 15(6), 2009, 593-602.

19. BAUER, K., PARISE, C., CAGGIANO, V., Use of ER/PR/HER2 subtypes in conjunction with the 2007 St Gallen Consensus Statement for early breast cancer. BMC Cancer, 10, 2010, 228.

20. MEHEDINTU, C., BRATILA, E., BERCEANU, C., CIRSTOIU, M., BARAC, R. I., et al., Comparison of Tumor - Infiltrating Lymphocytes Between Primary and Metastatic Tumors in Her2+ and HER2-Breast Cancer Patients, Rev. Chim., 69(11), 2018, 3133-3137.

21. JOENSUU, K., LEIDENIUS, M., KERO, M., ANDERSSON, LC., HORWITZ, KB., AND HEIKKILÄ, P., ER, PR, HER2, Ki-67 and CK5 in early and late relapsing breast cancer reduced CK5 expression in metastases, Breast Cancer (Auckl), 7, 2013, 23-34.

22. PEROU, C.M., SØRLIE, T., EISEN, M.B., VAN DE RIJN, M., JEFFREY, S.S., REES, C.A., POLLACK, J.R., ROSS, D.T., JOHNSEN, H., AKSLEN, L, A., ET AL., Molecular portraits of human breast tumours. Nature, 406(6797), 2000, $747-52$.

23. SØRliE, T., PEROU, C.M., TIBSHIRANI, R., AASF, T., GEISLERG, S., JOHNSENB, H., HASTIEE, T., EISENH, MB., VAN DE RIJNI, M., JEFFREYJ, S.S,, ET AL., Gene expression patterns of breast carcinomas distinguish tumor subclasses with clinical implications, Proc Natl Acad Sci, 98(19), 2001, 108, $69-74$.

Manuscript received: 20.12 .2019 